\title{
SEED YIELD AND FATTY ACIDS COMPOSITION OF SESAME GENOTYPES AS AFFECTED BY FOLIAR APPLICATION OF IRON NANO-CHELATE AND FULVIC ACID UNDER DROUGHT STRESS
}

\author{
AyoubizAdeH, N. ${ }^{1}$ - LAeI, G. ${ }^{2,{ }^{*}}$ - AMINI DeHAGHI, M. ${ }^{3}$ - MASOUd SinAKI, J. ${ }^{2}$ - REZVAN, S. ${ }^{2}$ \\ ${ }^{1}$ Agronomy Department, Damghan Branch, Islamic Azad University, Damghan, Iran \\ ${ }^{2}$ Agriculture Faculty, Damghan Branch, Islamic Azad University, Damghan, Iran \\ ${ }^{3}$ Faculty of Agriculture, Shahed University, Tehran, Iran \\ *Corresponding author \\ e-mail: g.laei@damghaniau.ac.ir
}

(Received 12 $2^{\text {th }}$ Jul 2018; accepted 22 ${ }^{\text {nd }}$ Aug 2018)

\begin{abstract}
The aims of this study were to investigate the effects of drought stress (full irrigation as control, irrigation up to 50\% seed ripening and flowering) and foliar application of iron nano-chelate and fulvic acid compounds on the quantitative and qualitative yield of two sesame (Sesamum indicum L.) genotypes (Dashtestan and Halil). A factorial split plot experiment was conducted based on randomized complete block design (RCBD) with three replications at Shahed University, Tehran, Iran, for two consecutive years. Results indicated that the effects of drought stress, foliar application, and genotype were significant on number of capsule, number of seed, 1000-seed weight, grain yield, biological yield, LAI, number of leaf, oil percent, oil yield, and fatty acid components. Severe drought stress significantly decreased number of capsule, number of seed, 1000-seed weight, grain yield, biological yield, LAI, and number of leaf in comparison to non-stress conditions in the two growing seasons. Co-application of iron nano-chelate and fulvic acid was the most effective treatment, which enhanced number of capsule, number of seed, 1000-seed weight, grain yield, biological yield, LAI, and number of leaf in compared to the control treatment. In the foliar application $\times$ genotype interaction effects, the highest grain yield was achieved in Halil genotype under co-application of iron nano-chelate and fulvic acid in the first year $\left(2507.2 \mathrm{~kg} \mathrm{ha}^{-1}\right)$ and foliar application of iron nano-chelate in the second year $\left(2712.7 \mathrm{~kg} \cdot \mathrm{ha}^{-1}\right)$. The highest LAI was obtained at the full irrigation treatments (control) in Halil (4.46) and Dashtestan (2.76) genotypes during the first and second years respectively. Results demonstrated that through drought stress, oleic content, linoleic content, linolenic content and palmitic content, were enhanced in plants during two years of experiment and oil percent and oil yield were decreased. Under moderate stress level was observed the highest oil percent (48.29 and 53.27\% during the first and second year, respectively) and seed oil yield (998.6 kg.ha-1 during the second year). In general, drought stress increased the content of non-saturated fatty acids such as oleic, linoleic, and linolenic acids. Co-application of iron nano-chelate and fulvic acid enhanced oleic and linolenic acid contents, but on the other hand, non-application of fertilizer had the highest content of palmitic and stearic acids. The highest palmetic acid content was obtained from Dashtestan genotype (12.09 and 11.41\% first and second years, respectively) under non application of fertilizer. Overall, the results showed that this fatty acid did not have a good reaction to fertilizer application. Finally, the results showed that severe drought stress (irrigation up to $50 \%$ flowering, equivalent to $65 \mathrm{BBCH}$ ) led to a decrease in the quantitative and qualitative yield that it can be increased by foliar application of iron nano-chelates and organic compounds such as fulvic acid.
\end{abstract}

Keywords: BBCH scale, grain yield, irrigation regimes, nano-chelate, seed oil, unsaturated fatty acid

\section{Introduction}

Sesame (Sesamum indicum L.) is one of the earliest oilseeds grown in most tropical and subtropical regions. Due to low water requirement, sesame is generally cultivated as 
main cultivation or intercropping, as well as, as a second cultivation after cereals (Bagheri et al., 2013). This plant plays an important role in human health due to its high oil content (47 to 52\%) and proper quality (low cholesterol and have some antioxidants), as well as a good protein content (19 to 25\%) (Kassab et al., 2005; Gharby et al., 2017). Recent studies have shown that the oil of this plant is very stable due to the presence of different fatty acids (such as oleic, linoleic, palmitic, and stearic) and a number of antioxidants (such as sesamin, sesamolin, and sesamol) (Were et al., 2006).

Drought stress is major limiting environmental factor for growth and crop production in the world especially in arid and semi-arid regions (Kadkhodaei et al., 2014), in addition to, the stress is one of the main factors affecting seed composition, protein content, grain yield and finally the quality of sesame seeds (Thornton et al., 2014). Sesame plant has favorable growth in arid and semi-arid regions with minimum rainfall that is more distributed at reproductive stages. In recent years, drought resistant genotypes of sesame have been aimed at increasing the production of protein and oil replacing old genotypes (Thornton et al., 2014). Oil and protein content of sesame seeds varies depending on cultivar and environmental conditions. By increase drought stress, the amount of oleic acid decreased in two sesame cultivars, but the amount of linoleic acid was not affected by drought stress (Ozkan and Kulak, 2013). Reported that the effects of drought stress and genotypes were significant on the amount of oil and the composition of essential oil fatty acids of sesame (Kadkhodaei et al., 2014). Water stress before and after flowering, increase the means of the quality trait of Brassica napus L. (Masoud Sinaki et al., 2007).

Under drought stress due to osmotic potential loss, nutrient availability is one of the most influential factors in plant growth and development. On the other hand, most of the agricultural soils of Iran are facing low $\mathrm{pH}$, leading to low nutrients solubility. Under such a condition, application of fertilizers may result in increased nutrients solubility (Maleki-Farahani and Aghighi Shahverdi, 2015). Application of nanofertilizers can be an effective step to achieve a sustainable agriculture with regard to the fact that nano-fertilizer enhances nutrients release process in the soil (Maleki-Farahani and Aghighi Shahverdi, 2015). Nano-fertilizers are a new category of fertilizers with element size less than $100 \mathrm{~nm}$. It has been reported that the application of $4 \mathrm{~kg}$ of iron nano-chelate increased spinach yield by $76 \%$ compared to the control (LadanMoghadam et al., 2012).

Organic acids are one of the main components of organic carbon, which naturally formed through the biological and microbial decomposition of animals and plants. Humic and fulvic acids are the main components of organic acids (Miao et al., 2018). Fulvic acid is the most active humic compound that dissolves minerals in water and easily transfers nutrients through a complex to the plant. Also, the acid can solve vitamins, isoenzymes, hormones, and antibiotics, thereby improving plant growth and development (Dahmardeh et al., 2015). Tadayyon et al. (2017) reported that the effect of spraying humic acids and iron increases yield, yield components, protein, and oil content in Niger plant (Guizotia abyssinica L.).

Considering the importance of drought stress as the growth-limiting factor and production plant, as well as the importance of plant nutrition under such a conditions, investigate the reactions of sesame genotypes (as a drought tolerant plant) to drought stress and exogenous application of iron and fulvic acid seems to be obligatory. Hence, the aims of the study, investigation yielding and qualitative responses of sesame 
genotypes to foliar application of iron nano-chelate and fulvic acid under drought stress condition.

\section{Materials and methods}

In order to investigate the effects of drought stress and foliar application of iron nano-chelate and fulvic acid on quantitative and qualitative characteristics of two sesame genotypes was conducted a factorial-split plot experiment based on randomized complete block design with three replications in Shahed University, Tehran, Iran $\left(35^{\circ}\right.$ $34^{\prime} \mathrm{N}$ latitude and $51^{\circ} 34^{\prime} \mathrm{E}$ longitude) during two consecutive years.

The experimental factors consisted of drought stress based on $\mathrm{BBCH}$, full irrigation as control, irrigation up to $50 \%$ seed ripening ( $75 \mathrm{BBCH}=$ mild stress) and irrigation up to $50 \%$ flowering ( $65 \mathrm{BBCH}=$ severe stress), in the main plots and the foliar application of iron nano-chelate and fulvic acid and two sesame genotypes (Dashtestan and Halil) were located in subplots. Characteristics of the genotypes tested in this research persented in Table 1. Soil fertilizers were added to the experimental farmland based on the soil test during farm preparation (Table 2).

Table 1. Characteristics of the genotypes tested in this research

\begin{tabular}{c|c|c|c|c|c|c|c}
\hline Genotypes & $\begin{array}{c}\text { Plant } \\
\text { height } \\
\text { (cm) }\end{array}$ & $\begin{array}{c}\text { Seed } \\
\text { color }\end{array}$ & $\begin{array}{c}\mathbf{1 0 0 0 - s e e d} \\
\text { weight } \\
(\mathbf{g})\end{array}$ & $\begin{array}{c}\text { Oil } \\
\text { percent } \\
(\boldsymbol{\%})\end{array}$ & $\begin{array}{c}\text { Grain yield } \\
\left(\mathbf{k g}^{-\mathbf{1}}\right)\end{array}$ & $\begin{array}{c}\text { Number of } \\
\text { inflorescences } \\
\text { in axis }\end{array}$ & $\begin{array}{c}\text { Reaction to } \\
\text { dehydration }\end{array}$ \\
\hline Dashtestan & $142-145$ & $\begin{array}{c}\text { Light } \\
\text { brown }\end{array}$ & 4 & 57 & $2100-2400$ & 1 & $\begin{array}{c}\text { Relatively } \\
\text { tolerant }\end{array}$ \\
\hline Halil & 175 & Brown & 3.4 & 54 & 1520 & 1 & $\begin{array}{c}\text { Relatively } \\
\text { tolerant }\end{array}$ \\
\hline
\end{tabular}

Table 2. Physicochemical characteristics of the experimental farm soil in depth of 0 to $30 \mathrm{~cm}$

\begin{tabular}{c|c|c|c|c|c|c|c|c}
\hline & $\begin{array}{c}\text { Soil } \\
\text { texture }\end{array}$ & $\mathbf{p H}$ & $\begin{array}{c}\text { Electrical } \\
\text { conductivity } \\
(\mathbf{d S} / \mathbf{m})\end{array}$ & $\begin{array}{c}\text { Organic } \\
\text { carbon } \\
(\%)\end{array}$ & $\begin{array}{c}\text { Nitrogen } \\
(\mathbf{m g} / \mathbf{k g})\end{array}$ & $\begin{array}{c}\text { Phosphorous } \\
(\mathbf{m g} / \mathbf{k g})\end{array}$ & $\begin{array}{c}\text { Potassium } \\
(\mathbf{m g} / \mathbf{k g})\end{array}$ & $\begin{array}{c}\text { Iron } \\
(\mathbf{m g} / \mathbf{k g})\end{array}$ \\
\hline $\begin{array}{c}\text { Experimental } \\
\text { farm }\end{array}$ & $\begin{array}{c}\text { Clay } \\
\text { loam }\end{array}$ & 8.1 & 2 & 1.11 & 1100 & 7.4 & 383.6 & 5.7 \\
\hline $\begin{array}{c}\text { Optimum } \\
\text { range }\end{array}$ & $\begin{array}{c}\text { Loam } \\
\text { and } \\
\text { sandy } \\
\text { loam }\end{array}$ & $\begin{array}{c}6.5- \\
7\end{array}$ & 1.51 & 2 & 2000 & 16 & 350 & 6.6 \\
\hline
\end{tabular}

Optimum range reference (Prajapat, 2010)

Each subplots sizes into main plot were $2 \times 3 \mathrm{~m}$ and consisted of five planting rows. The distance between the blocks and the main plot was $2 \mathrm{~m}$, the distance between the plants was $10 \mathrm{~cm}$, the distance between the rows was $55 \mathrm{~cm}$. The cultivation was carried out manually in May of both years. Before flowering, field irrigation was done in the same way (determination of irrigation time using class A evaporation pan based on 70 mm evapotranspiration). To apply drought stress, irrigation was discontinued when $50 \%$ of the planned flowering stage (for $65 \mathrm{BBCH}$ ) or $50 \%$ seed ripening (for $75 \mathrm{BBCH}$ ) (severe and moderate stress, respectively).

The extended BBCH scale considers 10 principle growth stages numbered from 0-9. For the sesame plant, we begin with the germination of seeds, or shoot development in 
cuttings or stumps (stage 0). This stage is than followed by vegetative growth considered under 3 macro-stages corresponding to leaf development in seedling in the nursery or on branches (stage 1), formation of branches (stage 2) and elongation of branches (stage 3). Next are inflorescence emergence and flower development (stage 5), flowering (stage 6), development of fruit (stage 7), ripening of the fruit and seed (stage 8) and senescence (stage 9). Note that the development of vegetative harvestable parts corresponding to stage 4 was note considered because it does not apply to the sesame plant (Attibayeba et al., 2010).

For iron and fulvic acid treatments were used iron nano-chelated 9\% $\left(10 \mathrm{~kg} \cdot \mathrm{ha}^{-1}\right)$ and Fulvic Acid Fert Star Fulvabon Potassic that containing 45\% fulvic acid, 15\% humic acid and $15 \%$ soluble potassium $\left(2 \mathrm{~kg} \cdot \mathrm{ha}^{-1}\right)$, respectively. Foliar application of these treatments was used during two stages of the beginning of flowering and seed ripening (according to the manufacturer's recommendation).

In each year, in early September (after physiological maturity), sampling for measurement grain yield and yield components from each experimental unit was performed taking into account marginal effects. The ASOC Officinal Method 972.28 (41.1.22) method was used to determine the amount of seed oil by hot extraction method from Soxhlet apparatus. For estimation of total oil content, $10 \mathrm{~g}$ of seeds were crushed and extracted with petroleum ether for $4 \mathrm{~h}$ in a Soxhlet apparatus according to the method described by AOAC. The extract was concentrated under reduced pressure. The total seed oil content were calculated as percentage of sesame seeds (Hussein et al., 2016). Oil yield was calculated by using grain yield $\times$ oil percent (Malacrida et al., 2011).

In order to determine the amount of fatty acids, $50 \mathrm{~g}$ of crushed grains mixed with hexane (one to four ratio) and placed on a shaker for 48 hours, then, after separating the solvent from the solution, the oil of $7 \mathrm{~mL}$ of methanol potassium was added (Farhoosh et al., 2009). After dehumidification of oil with potassium sulfate, the samples were injected into a mass spectrometric gas chromatography machine (Acmw 6000 (GC/MASS) YOUNG LIN, Korea) with a column in length, inner diameter, and thickness $100 \mathrm{~m}, 0.25 \mathrm{~mm}$, and $0.2 \mu \mathrm{m}$, respectively. The injection rate was $0.5 \mu \mathrm{L}$. By comparing samples peak with standard peak based on RRT of peaks, the most important saturated and unsaturated fatty acids were detected and their values were determined from the calculation of the surface area under the curve of the peak (RezvaniMoghadam et al., 2014).

All of the data obtained for two consecutive years were subjected to analysis of variance using SAS software (Statistical Analysis Software, 9.2). Differences among the treatments were assessed with the LSD (least significant difference) only when the ANOVA F-test showed significance at $\mathrm{P}=0.05$. Correlation between traits was determined using the SAS software under two stress and non-stress conditions for the mean of two years.

\section{Results}

\section{Yield and yield components}

Analysis of variance (ANOVA) revealed that the drought stress, foliar application, and genotype had significant effects on number of capsule per plant, number of seed per capsule, 1000-seed weight, grain yield, biological yield, LAI, and number of leaf per plant in both years (Table 3). 
Table 3. Effects of drought stress and foliar application treatments on growing traits and yield components of two genotypes of sesame

\begin{tabular}{|c|c|c|c|c|c|c|c|c|c|c|c|c|c|c|}
\hline \multirow[t]{2}{*}{ Treatment } & \multicolumn{2}{|c|}{$\begin{array}{c}\text { Number of } \\
\text { capsule per plant }\end{array}$} & \multicolumn{2}{|c|}{$\begin{array}{c}\text { Number of seed per } \\
\text { capsule }\end{array}$} & \multicolumn{2}{|c|}{$\begin{array}{c}\text { 1000-seed weight } \\
\text { (g) }\end{array}$} & \multicolumn{2}{|c|}{$\begin{array}{c}\text { Grain yield } \\
\left(\mathrm{kg}^{\mathrm{h}} \mathrm{ha}^{-1}\right)\end{array}$} & \multicolumn{2}{|c|}{$\begin{array}{c}\text { Biological yield } \\
\left(\mathrm{kg}^{\circ} \mathrm{ha}^{-1}\right)\end{array}$} & \multicolumn{2}{|c|}{ LAI } & \multicolumn{2}{|c|}{$\begin{array}{c}\text { Number of leaf } \\
\text { per plant }\end{array}$} \\
\hline & 2015 & 2016 & 2015 & 2016 & 2015 & 2016 & 2015 & 2016 & 2015 & 2016 & 2015 & 2016 & 2015 & 2016 \\
\hline \multicolumn{15}{|l|}{$\begin{array}{l}\text { Drought stress } \\
\text { (D) }\end{array}$} \\
\hline $\begin{array}{l}\text { Full irrigation } \\
\text { (control) }\end{array}$ & 83.27 & 138.2 & 4841.1 & 9234.7 & 3.36 & 2.50 & 2302.3 & 1794.3 & 12922.6 & 11386.2 & 3.96 & 2.42 & 181.8 & 329.3 \\
\hline Severe stress & 79.44 & 103.4 & 3958.2 & 5304.1 & 2.74 & 2.22 & 1546.0 & 1548.0 & 11502.5 & 8785.5 & 3.49 & 1.64 & 166.4 & 299.4 \\
\hline Moderate stress & 81.23 & 144.7 & 4658.3 & 9936.4 & 3.15 & 2.43 & 2063.1 & 1842.9 & 13038.3 & 11906.3 & 3.68 & 1.95 & 177.4 & 340.5 \\
\hline Mean & 81.30 & 128.7 & 4485.8 & 8158.4 & 3.09 & 2.38 & 1970.4 & 1728.4 & 12487.8 & 10692.6 & 3.71 & 2.00 & 175.2 & 323.1 \\
\hline St D $( \pm)$ & 1.6 & 9.11 & 148.7 & 700.0 & 0.06 & 0.07 & 90.93 & 153.8 & 446.5 & 751.1 & 0.14 & 0.14 & 3.06 & 13.05 \\
\hline $\operatorname{LSD}(P=0.05)$ & 2.64 & 27.9 & 461.4 & 2071.8 & 0.16 & 0.15 & 255.4 & 185.9 & 1040.6 & 1904.1 & 0.42 & 0.44 & 11.72 & 33.22 \\
\hline \multicolumn{15}{|l|}{$\begin{array}{l}\text { Foliar } \\
\text { application }(\mathbf{F})\end{array}$} \\
\hline Control & 78.42 & 110.2 & 3913.5 & 5954.2 & 2.69 & 2.18 & 1510.3 & 1433.9 & 10849.5 & 8937.1 & 3.20 & 1.67 & 159.3 & 283.4 \\
\hline $\begin{array}{l}\text { Iron nano- } \\
\text { chelate (IN) }\end{array}$ & 72.78 & 143.6 & 4935.4 & 9649.6 & 3.13 & 2.53 & 2181.7 & 2023.2 & 12656.9 & 11340.0 & 3.72 & 1.89 & 175.3 & 353.3 \\
\hline Fulvic acid (FA) & 79.38 & 119.0 & 4411.2 & 8150.0 & 3.12 & 2.36 & 1943.3 & 1652.4 & 12429.9 & 11579.1 & 3.73 & 2.36 & 176.5 & 334.6 \\
\hline IN + FA & 84.68 & 142.2 & 4683.3 & 8879.8 & 3.40 & 2.45 & 2246.4 & 1804.1 & 14014.8 & 10914.4 & 4.20 & 2.09 & 189.5 & 321.0 \\
\hline Mean & 81.32 & 124.3 & 4485.8 & 7917.9 & 3.09 & 2.36 & 1970.4 & 1703.2 & 12487.8 & 10618.7 & 3.71 & 1.97 & 175.2 & 323.8 \\
\hline St D $( \pm)$ & 1.80 & 10.71 & 172.7 & 878.9 & 0.08 & 0.08 & 111.1 & 169.7 & 463.3 & 892.6 & 0.15 & 0.18 & 3.02 & 14.30 \\
\hline $\operatorname{LSD}(P=0.05)$ & 3.43 & 26.4 & 329.9 & 1875.8 & 0.13 & 0.17 & 158.2 & 402.6 & 809.3 & 1498.6 & 0.25 & 0.38 & 4.24 & 41.48 \\
\hline \multicolumn{15}{|l|}{ Genotype (G) } \\
\hline Dashtestan & 75.44 & 127.4 & 4185.7 & 7503.4 & 2.96 & 2.22 & 1768.2 & 1346.2 & 11441.0 & 12017.3 & 3.19 & 2.16 & 172.1 & 323.8 \\
\hline Halil & 87.19 & 130.1 & 4786.0 & 8813.4 & 3.21 & 2.54 & 2172.7 & 2110.7 & 13534.6 & 9367.9 & 4.23 & 1.84 & 178.3 & 322.3 \\
\hline Mean & 81.32 & 128.7 & 4485.8 & 8158.4 & 3.09 & 2.38 & 1970.4 & 1728.4 & 12487.8 & 10692.6 & 3.71 & 2.00 & 175.2 & 323.1 \\
\hline St D $( \pm)$ & 0.89 & 8.02 & 123.5 & 665.0 & 0.06 & 0.05 & 84.78 & 110.5 & 338.8 & 608.5 & 0.09 & 0.13 & 2.73 & 10.84 \\
\hline $\operatorname{LSD}(P=0.05)$ & 2.42 & NS & 233.3 & NS & 0.09 & 0.12 & 111.9 & 284.7 & 572.2 & 1059.7 & 0.17 & 0.27 & 2.99 & NS \\
\hline \multicolumn{15}{|l|}{$\begin{array}{l}\text { Interaction } \\
\text { effect }\end{array}$} \\
\hline LSD of $D \times F$ & NS & NS & NS & 3249 & NS & NS & NS & NS & 1401.8 & 2595.7 & NS & 0.66 & 7.34 & NS \\
\hline LSD of $D \times G$ & NS & NS & NS & NS & NS & 0.20 & NS & NS & 991.1 & NS & 0.30 & 0.46 & 5.19 & NS \\
\hline $\mathrm{LSD}$ of $\mathrm{F} \times \mathrm{G}$ & NS & 37.37 & 466.6 & 2652.8 & NS & 0.24 & 223.8 & 569.4 & 1144.5 & 2119.4 & NS & NS & NS & 58.64 \\
\hline $\begin{array}{l}\text { LSD of } D \times F \times \\
G\end{array}$ & NS & NS & NS & 4594.8 & NS & NS & NS & NS & NS & 3670.9 & NS & NS & 10.38 & NS \\
\hline
\end{tabular}

*Each year's data were analyzed separately 
The foliar application $\times$ genotype interaction effects were significant for the number of seed, grain yield, and biological yield in the second year (Table 3). Severe drought stress significantly decreased number of capsule, number of seed, 1000-seed weight, grain yield, biological yield, LAI, and number of leaf in compared to the non-stress conditions during the two growing seasons (Table 3). This reduction was 4.59 and $25.18 \%$ for number of capsules, 18.23 and $42.56 \%$ for number of seed, 18.45 and $11.2 \%$ for 1000 -seed weight, 32.84 and $13.72 \%$ for grain yield, 10.98 and $22.84 \%$ for biological yield, 11.86 and $32.23 \%$ for LAI, and 8.47 and $9.07 \%$ for number of leaf in first and second years respectively.

The foliar application of iron nano-chelate and fulvic acid increased number of capsule, number of seed, 1000-seed weight, grain yield, biological yield, LAI, and number of leaf in both years (Table 3). Co-application of iron nano-chelate and fulvic acid was the most effective treatment, which enhanced number of capsule, number of seed, 1000-seed weight, grain yield, biological yield, LAI, and number of leaf in compared to the control treatment (Table 3). In the first year, the highest number of capsule (84.68 per plant), 1000-seed weight (3.40 g), grain yield $\left(2246.4 \mathrm{~kg} . \mathrm{ha}^{-1}\right)$, biological yield (14014.8 kg.ha-1), LAI (4.20), and number of leaf (189.5 per plant) were observed in co-application of iron nano-chelate and fulvic acid. In the second year, the highest number of capsules (143.6 per plant), number of seed (9649.6 per capsule), 1000 -seed weight $(2.53 \mathrm{~g})$, grain yield $\left(2023.2 \mathrm{~kg} \mathrm{ha}^{-1}\right)$, and number of leaf (353.3 per plant) were achieved iron nano-chelate application (Table 3). Most of the agronomic traits studied were highest in Halil genotype compared to Dashtestan genotype in both years (Table 3).

In the foliar application $\times$ genotype interaction effects, the highest number of seed was observed the application of iron nano-chelate on Dashtestan genotype in the first year (5027.7 per plant) and application of iron nano-chelate on Halil genotype in the second year (12399 per plant). In other words, had a high efficiency of the foliar application of iron nano-chelate on Deshestan and Halil genotypes in the first and second year's respectively (Figure 1).

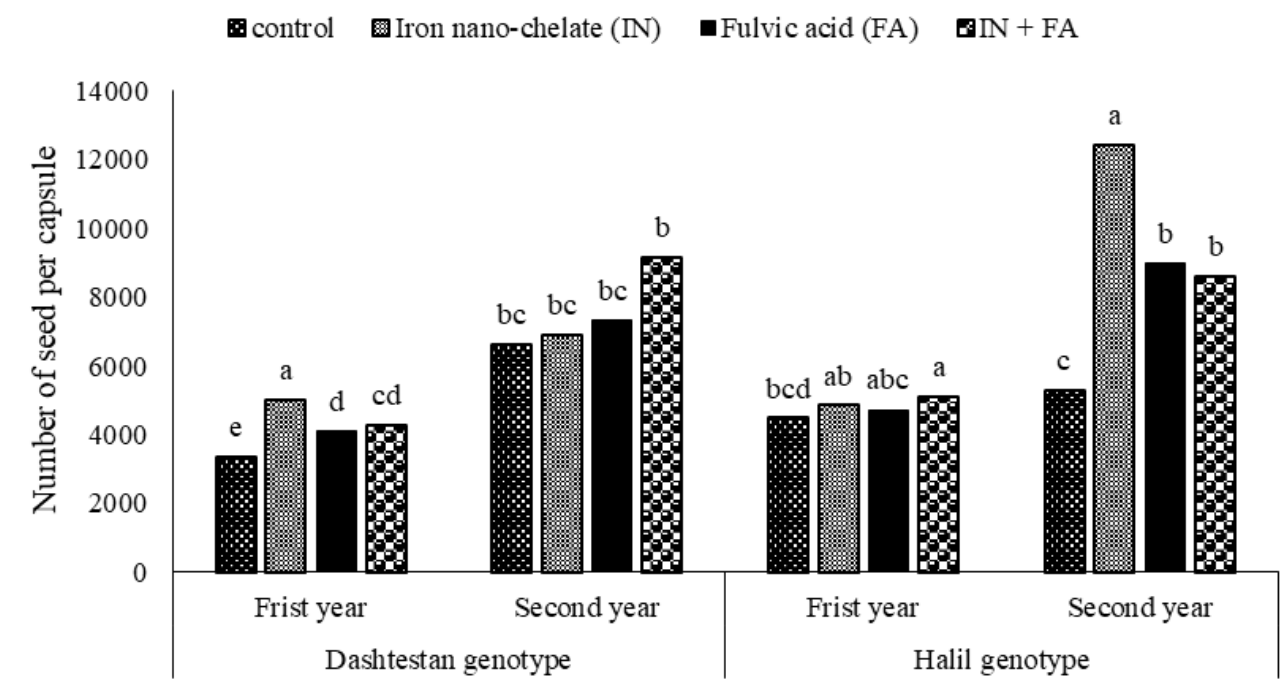

Figure 1. Interaction effects of foliar application $\times$ genotype on number of seed of sesame *Each year's data were analyzed separately (Based on the LSD mean comparison test, nonsimilar alphanumeric characters differ significantly in each year) 
In the foliar application $\times$ genotype interaction effects, the highest grain yield was achieved in Halil genotype under co-application of iron nano-chelate and fulvic acid in the first year $\left(2507.2 \mathrm{~kg} \cdot \mathrm{ha}^{-1}\right)$ and foliar application of iron nano-chelate in the second year (2712.7 kg.ha-1) (Figure 2).

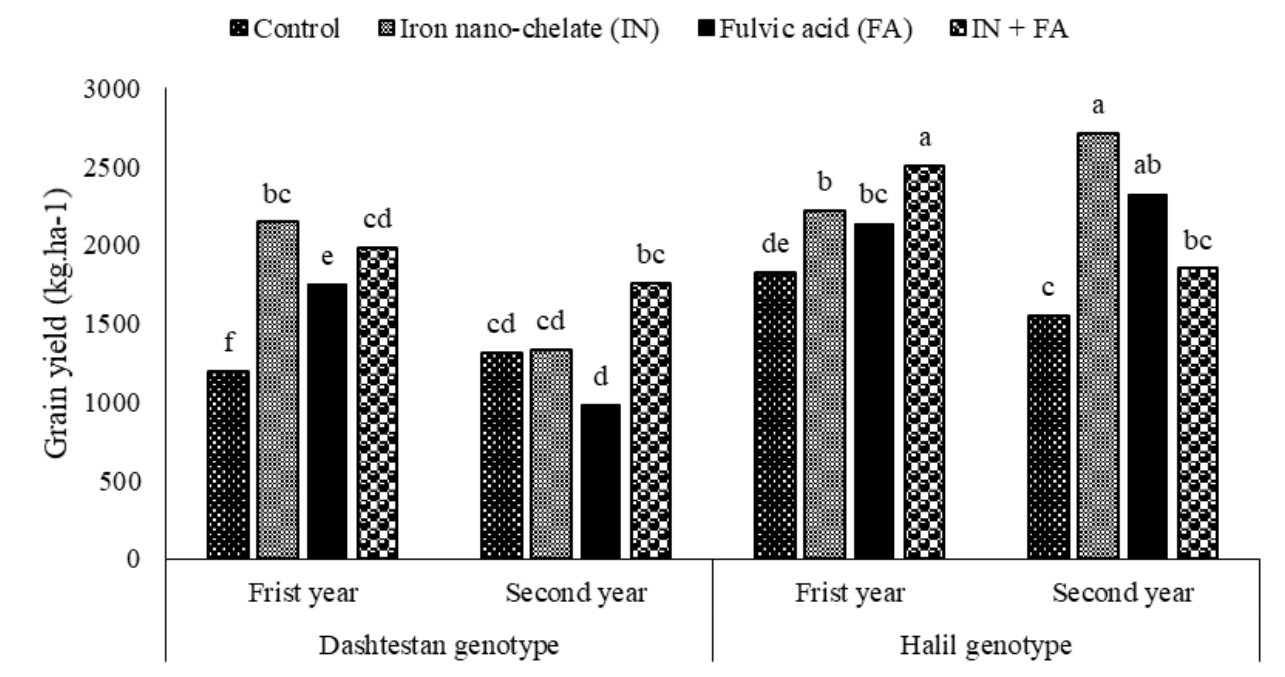

Figure 2. Interaction effects of foliar application $\times$ genotype on grain yield of sesame *Each year's data were analyzed separately (Based on the LSD mean comparison test, nonsimilar alphanumeric characters differ significantly in each year)

Co-application of iron nano-chelate and fulvic acid in Dashtestan and Halil genotypes had the highest biological yield (13972 and $15030.3 \mathrm{~kg}^{-h^{-1}}$ respectively) during the second and first years respectively. Non-application of fertilizer (control treatment) in Dashtestan and Halil genotypes had the lowest means of the trait during the first and second years respectively (Figure 3).

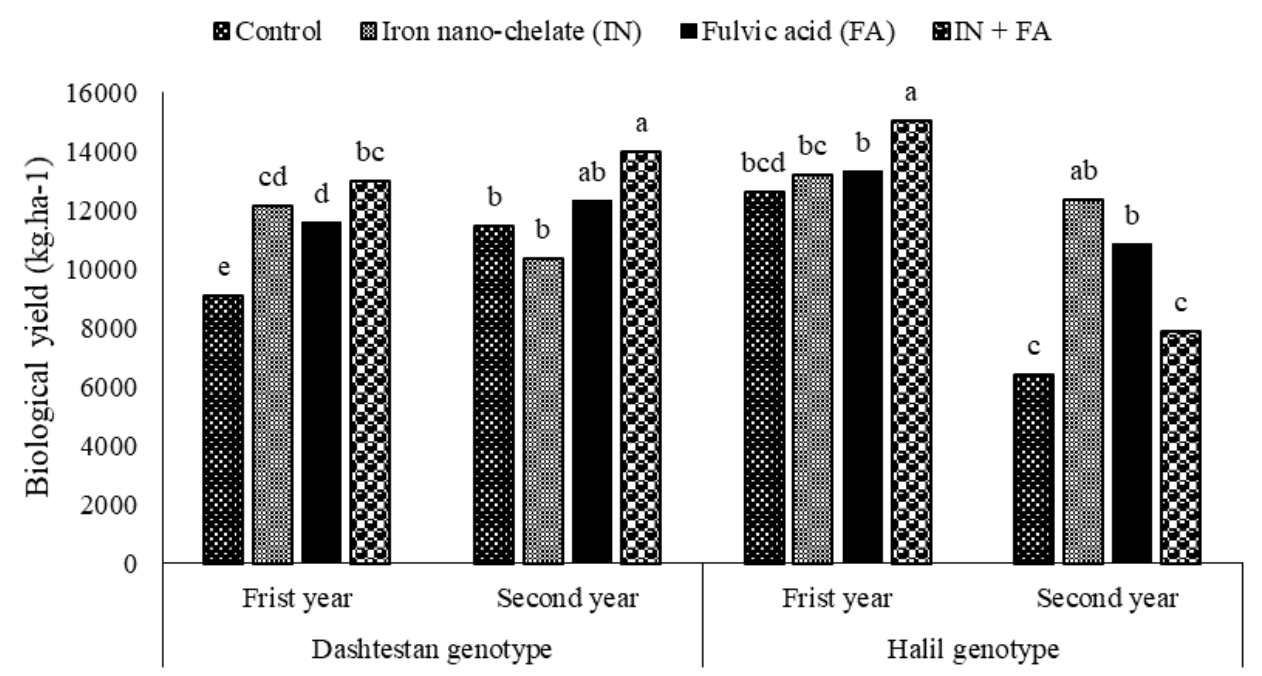

Figure 3. Interaction effects of foliar application $\times$ genotype on biological yield of sesame *Each year's data were analyzed separately (Based on the LSD mean comparison test, nonsimilar alphanumeric characters differ significantly in each year) 
Interaction effects of drought stress $\times$ foliar application on biological yield of sesame showed the highest mean of the trait achieved in the co-application of iron nano-chelate + fulvic acid under moderate stress $\left(14660.8 \mathrm{~kg} \cdot \mathrm{ha}^{-1}\right)$ in first year and also, the application of fulvic acid under moderate stress $\left(14140 \mathrm{~kg}^{-h a^{-1}}\right)$ in second year (Figure 4). Comparing the results of biological yield, it is obvious that when plants encountered drought at the flowering stage (severe stress), biological yield was decreased especially in the first year, but in the second year, the foliar application reduced the negative effects of drought stress.

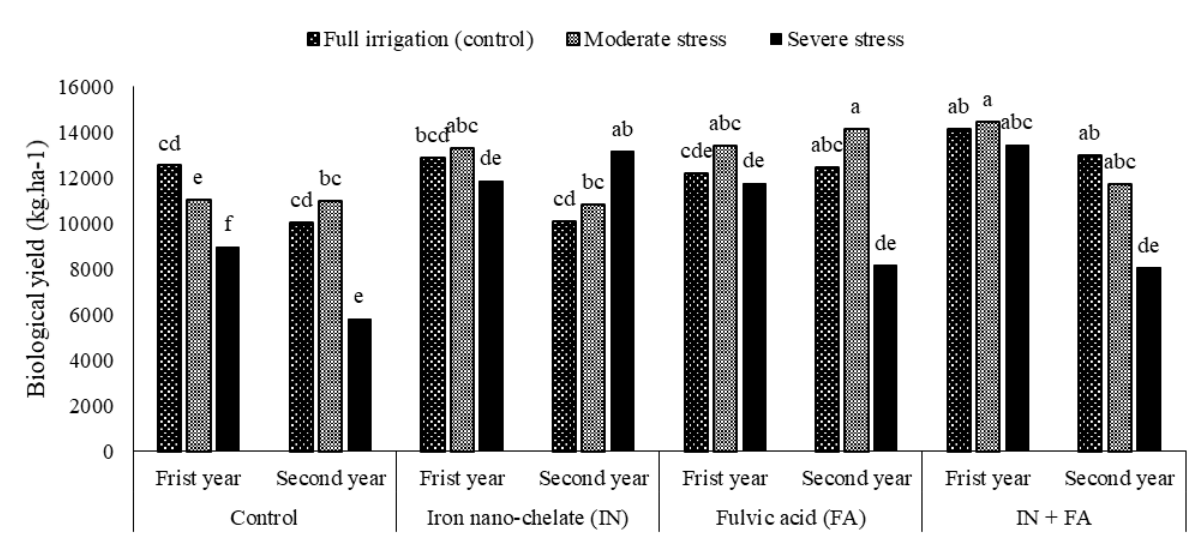

Figure 4. Interaction effects of drought stress $\times$ foliar application on biological yield of sesame *Each year's data were analyzed separately (Based on the LSD mean comparison test, nonsimilar alphanumeric characters differ significantly in each year)

The highest LAI was obtained at the full irrigation treatments (control) in Halil (4.46) and Dashtestan (2.76) genotypes during the first and second years respectively. The lowest mean of the trait was observed in Halil genotype during the second year (Figure 5).

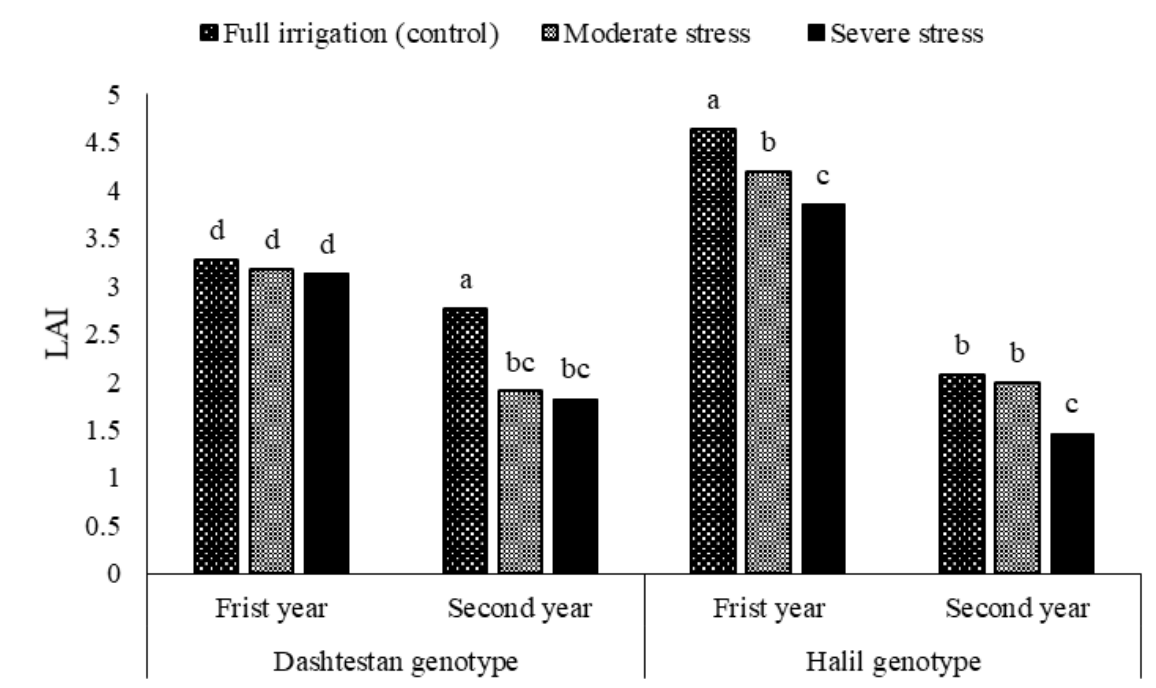

Figure 5. Interaction effects of drought stress $\times$ genotype on LAI of sesame

*Each year's data were analyzed separately (Based on the LSD mean comparison test, nonsimilar alphanumeric characters differ significantly in each year) 


\section{Qualitative attributes}

The effect of drought stress was significant on oil percent, oil yield, and fatty acid composition such as oleic, linoleic, linolenic, palmitic, stearic and arachidic acids content in both years except for the linolenic content in the first year (Table 4). Results demonstrated that through drought stress, oleic, linoleic, linolenic, and palmitic contents, were enhanced in plants during two years of experiment and oil percent and oil yield were decreased (Table 4). Under moderate stress, condition was observed the highest oil percent (48.29 and 53.27\% during the first and second years respectively) and seed oil yield (998.6 kg.ha ${ }^{-1}$ during the second year). In general, drought stress increased the content of non-saturated fatty acids such as oleic, linoleic, and linolenic acids.

The effect of the foliar application was significant on oil percent, oil yield, contents of oleic, linoleic, linolenic, palmitic, stearic and arachidic acids in both years except for the oleic acid content in the first year (Table 4). The highest oil percent (48.52 and $50.22 \%$ in the first and second years respectively) and oil yield (1062.9 and 1032.9 kg.ha ${ }^{-1}$ in the first and second years respectively) was achieved in the application of iron nano-chelate (Table 4). Co-application of iron nano-chelate and fulvic acid enhanced oleic and linolenic acid contents, but on the other hand, non-application of fertilizer had the highest content of palmitic and stearic acids. The effect of sesame genotype on oil yield, the content of oleic, linoleic, linolenic, palmitic, stearic, and arachidic acids was significant (Table 4). Results indicated that Halil genotype had the highest oil yield and content of oleic, linoleic, palmitic, and stearic acids. In the interaction effect of drought stress $\times$ foliar application, the highest linolenic acid content was observed in the application of iron nano-chelate alone and in combination with fulvic acid under drought stress conditions during both years. The lowest mean of the trait was achieved in non-application of fertilizer under full irrigation treatment (Figure 6).

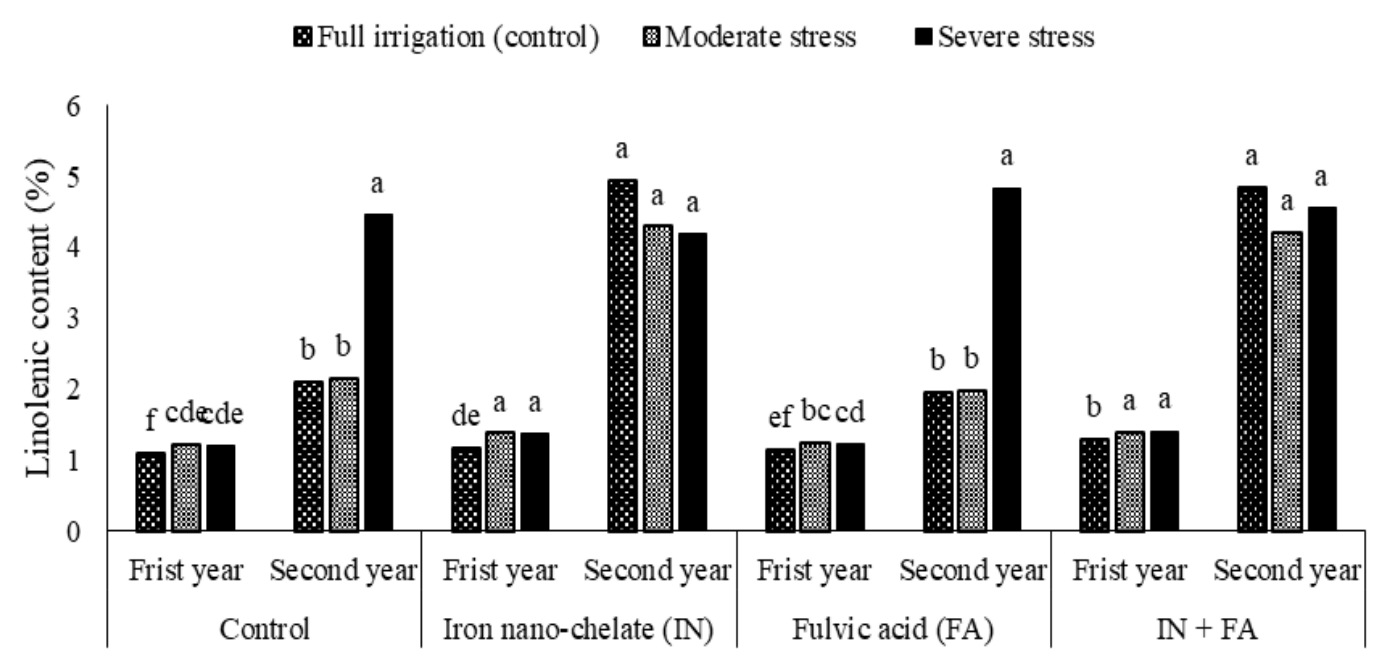

Figure 6. Interaction effects of drought stress $\times$ foliar application on linolenic acid content *Each year's data were analyzed separately (Based on the LSD mean comparison test, nonsimilar alphanumeric characters differ significantly in each year) 
Table 4. Effects of drought stress and foliar application treatments on qualitative attributes of two genotypes of sesame

\begin{tabular}{|c|c|c|c|c|c|c|c|c|c|c|c|c|c|c|c|c|}
\hline \multirow[t]{2}{*}{ Treatment } & \multicolumn{2}{|c|}{ Oil percent } & \multicolumn{2}{|c|}{$\begin{array}{c}\text { Oil yield } \\
\text { (kg.ha-1) }\end{array}$} & \multicolumn{2}{|c|}{$\begin{array}{c}\text { Oleic content } \\
(\%)\end{array}$} & \multicolumn{2}{|c|}{$\begin{array}{c}\text { Linoleic content } \\
(\%)\end{array}$} & \multicolumn{2}{|c|}{$\begin{array}{c}\text { Linolenic } \\
\text { content (\%) }\end{array}$} & \multicolumn{2}{|c|}{$\begin{array}{c}\text { Palmitic } \\
\text { content }(\%)\end{array}$} & \multicolumn{2}{|c|}{$\begin{array}{c}\text { Stearic } \\
\text { content }(\%)\end{array}$} & \multicolumn{2}{|c|}{$\begin{array}{c}\text { Arachidic } \\
\text { content }(\%)\end{array}$} \\
\hline & 2015 & 2016 & 2015 & 2016 & 2015 & 2016 & 2015 & 2016 & 2015 & 2016 & 2015 & 2016 & 2015 & 2016 & 2015 & 2016 \\
\hline \multicolumn{17}{|c|}{ Drought stress (D) } \\
\hline Full irrigation (control) & 45.76 & 47.25 & 1060.6 & 843.3 & 40.05 & 34.81 & 28.36 & 24.22 & 1.18 & 3.51 & 10.86 & 5.01 & 10.73 & 5.23 & 1.50 & 1.36 \\
\hline Severe stress & 43.71 & 40.41 & 677.3 & 627.0 & 41.50 & 39.60 & 30.08 & 27.03 & 1.30 & 4.50 & 10.05 & 10.07 & 9.45 & 11.07 & 1.43 & 4.35 \\
\hline Moderate stress & 48.29 & 53.27 & 1000.1 & 998.6 & 42.34 & 36.12 & 29.68 & 25.22 & 1.31 & 3.11 & 9.32 & 9.12 & 9.35 & 10.15 & 1.34 & 5.73 \\
\hline Mean & 45.92 & 46.98 & 912.6 & 823.0 & 41.30 & 36.84 & 29.37 & 25.49 & 1.26 & 3.71 & 10.08 & 8.06 & 9.84 & 8.82 & 1.42 & 3.81 \\
\hline St D $( \pm)$ & 0.71 & 1.10 & 47.59 & 78.8 & 0.54 & 0.70 & 0.47 & 0.56 & 0.03 & 0.28 & 0.30 & 0.37 & 0.35 & 0.41 & 0.04 & 0.24 \\
\hline $\operatorname{LSD}(P=0.05)$ & 2.95 & 4.94 & 148.9 & 162.2 & 1.90 & 2.05 & NS & 2.10 & 0.05 & 0.74 & 0.74 & 0.76 & 1.36 & 1.47 & 0.13 & 0.56 \\
\hline \multirow{2}{*}{\multicolumn{17}{|c|}{ Foliar application (F) }} \\
\hline & & & & & & & & & & & & & & & & \\
\hline Control & 43.83 & 42.95 & 664.0 & 613.2 & 40.03 & 34.25 & 29.1 & 24.30 & 1.18 & 2.84 & 10.8 & 9.85 & 10.4 & 10.32 & 1.43 & 4.90 \\
\hline Iron nano-chelate (IN) & 48.52 & 50.22 & 1062.9 & 1032.9 & 41.59 & 38.50 & 30.0 & 26.81 & 1.31 & 4.47 & 9.96 & 7.65 & 9.28 & 8.22 & 1.54 & 3.22 \\
\hline Fulvic acid (FA) & 44.60 & 46.30 & 870.5 & 760.6 & 41.77 & 35.99 & 28.3 & 23.94 & 1.21 & 2.99 & 10.1 & 7.62 & 10.1 & 8.37 & 1.35 & 3.66 \\
\hline $\mathrm{IN}+\mathrm{FA}$ & 46.74 & 48.44 & 1053.1 & 885.0 & 41.79 & 38.64 & 29.8 & 26.91 & 1.37 & 4.53 & 9.45 & 7.14 & 9.47 & 8.36 & 1.36 & 3.47 \\
\hline Mean & 45.92 & 46.49 & 912.6 & 802.3 & 41.30 & 36.25 & 29.3 & 25.02 & 1.26 & 3.43 & 10.0 & 8.37 & 9.84 & 8.97 & 1.42 & 3.93 \\
\hline St D $( \pm)$ & 0.83 & 1.66 & 57.1 & 90.98 & 0.64 & 0.84 & 0.56 & 0.63 & 0.03 & 0.31 & 0.35 & 0.64 & 0.41 & 0.75 & 0.05 & 0.49 \\
\hline $\operatorname{LSD}(P=0.05)$ & 2.14 & 3.50 & 91.3 & 202.6 & NS & 1.70 & 1.53 & 1.56 & 0.03 & 0.61 & 0.82 & 0.80 & 0.97 & 0.98 & 0.12 & 0.54 \\
\hline \multicolumn{17}{|l|}{ Genotype (G) } \\
\hline Dashtestan & 46.72 & 47.59 & 836.6 & 647.3 & 40.74 & 35.21 & 28.89 & 24.91 & 1.18 & 3.20 & 10.42 & 8.64 & 10.35 & 9.01 & 1.39 & 3.99 \\
\hline Halil & 45.13 & 46.37 & 988.7 & 998.6 & 41.85 & 38.47 & 29.85 & 26.07 & 1.35 & 4.21 & 9.73 & 7.49 & 9.34 & 8.62 & 1.45 & 3.63 \\
\hline Mean & 45.92 & 46.98 & 912.6 & 823.0 & 41.30 & 36.84 & 29.37 & 25.49 & 1.26 & 3.71 & 10.08 & 8.06 & 9.84 & 8.82 & 1.42 & 3.81 \\
\hline St D $( \pm)$ & 0.65 & 1.25 & 46.61 & 64.61 & 0.45 & 0.61 & 0.40 & 0.49 & 0.02 & 0.24 & 0.25 & 0.47 & 0.28 & 0.54 & 0.04 & 0.35 \\
\hline $\operatorname{LSD}(P=0.05)$ & 1.51 & $\mathrm{NS}$ & 64.62 & 143.3 & 1.27 & 1.20 & 1.08 & 1.10 & 0.02 & 0.43 & 0.58 & 0.56 & 0.68 & NS & $\mathrm{NS}$ & NS \\
\hline \multicolumn{17}{|l|}{ Interaction effect } \\
\hline LSD of $\mathrm{D} \times \mathrm{F}$ & NS & NS & NS & NS & NS & NS & NS & NS & 0.06 & 1.06 & NS & NS & NS & NS & 0.22 & NS \\
\hline LSD of $D \times G$ & NS & NS & NS & NS & NS & 2.08 & NS & NS & NS & 0.75 & NS & 0.98 & NS & 1.20 & NS & 0.66 \\
\hline LSD of $F \times G$ & NS & NS & 129.2 & 286.6 & 2.54 & NS & NS & NS & 0.05 & NS & 1.16 & 1.13 & 1.37 & 1.38 & NS & 0.76 \\
\hline LSD of $D \times F \times G$ & $\mathrm{NS}$ & $\mathrm{NS}$ & NS & NS & NS & NS & $\mathrm{NS}$ & 3.82 & $\mathrm{NS}$ & NS & $\mathrm{NS}$ & NS & $\mathrm{NS}$ & $\mathrm{NS}$ & 0.31 & 1.32 \\
\hline
\end{tabular}

Each year's data were analyzed separately 
The highest palmitic acid content was obtained from Dashtestan genotype (12.09 and $11.41 \%$ first and second years respectively) under non-application of fertilizer. Overall, the results showed that this fatty acid did not have a good reaction to fertilizer application (Figure 7). In the interaction effects of foliar application $\times$ genotype, nonapplication of fertilizer in Dashtestan genotype showed the highest stearic acid content in both years (11.85 and $11.33 \%$ respectively). Also, the foliar application of iron nanochelate on Dashtestan genotype had the highest mean of the trait $(11.05 \%)$ in the first year (Figure 8).

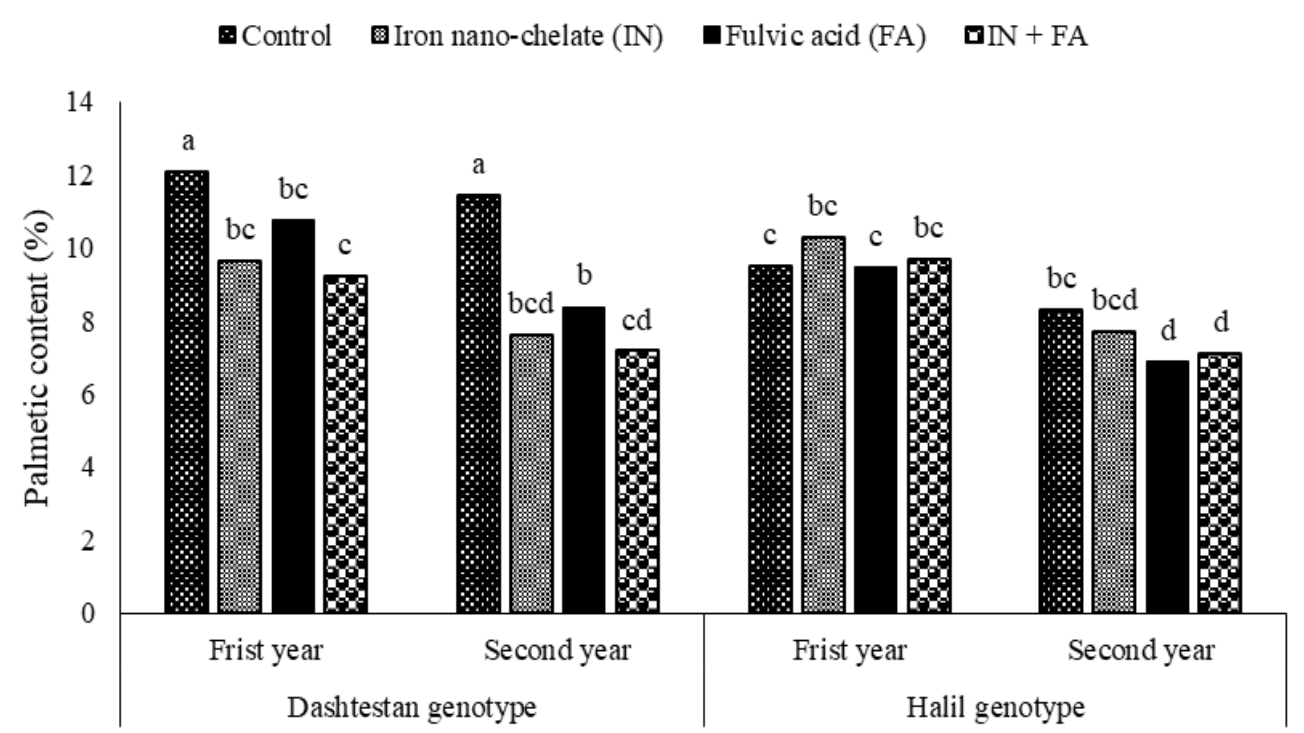

Figure 7. Interaction effects of foliar application $\times$ genotype on palmitic acid content *Each year's data were analyzed separately (Based on the LSD mean comparison test, nonsimilar alphanumeric characters differ significantly in each year)

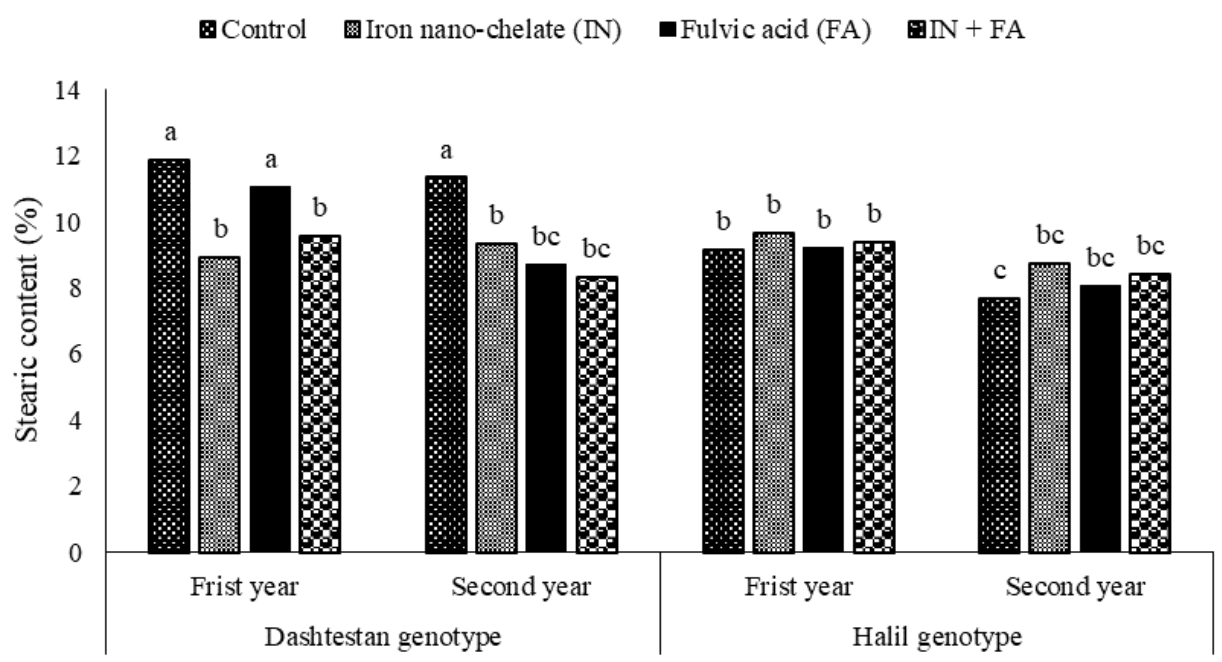

Figure 8. Interaction effects of foliar application $\times$ genotype on stearic acid content *Each year's data were analyzed separately (Based on the LSD mean comparison test, nonsimilar alphanumeric characters differ significantly in each year) 
Three-way interactions (drought stress $\times$ foliar application $\times$ genotype) was significant on arachidic acid content (Table 4). The highest mean of the trait was obtained non-application and the application of fulvic acid on Halil genotype under moderate stress level (7.6 and 6.91\% respectively) in the second year. In the first year, the foliar application of iron nano-chelate on Halil genotype under full irrigation treatment showed the highest mean $(1.31 \%)$ of the trait. The results indicated that the mean of this trait in the second year was higher than in the first year (Figure 9).

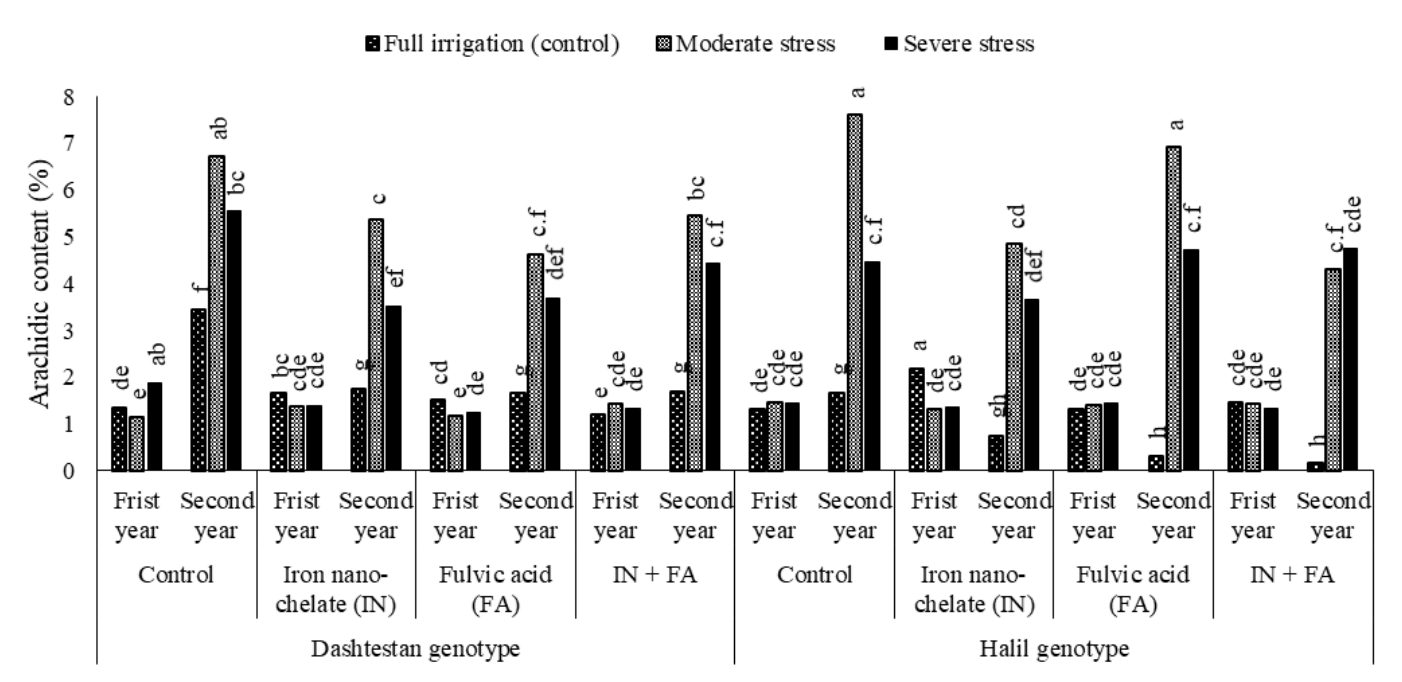

Figure 9. Interaction effects of drought stress $\times$ foliar application $\times$ genotype on arachidic acid content. *Each year's data were analyzed separately (Based on the LSD mean comparison test, non-similar alphanumeric characters differ significantly in each year)

\section{Correlation between traits}

Correlation coefficients among yielding and quality attributes of sesame under non drought stress and drought stress conditions presented in Tables 5 and 6, respectively. In general, the results of these two tables showed that under stress conditions, the correlation coefficients decreased compared to non-stress conditions. The significantly positive correlation observed between grain yield with 1000-seed weight, biological yield, and oil yield under non-stress and stress conditions.

The result in both years of the experiment revealed highly significant $(\mathrm{P}<0.01)$ positive correlation between LAI with number of capsule, number of seed, biological yield, oleic acid, and linoleic acid under two conditions. Oil content in oilseed plants is very important, thus, oil yield with 1000-seed weight and grain yield under non-stress and drought stress conditions had a positive correlation. The number of leaf had a significantly negative correlation with oleic, linoleic, linolenic, palmitic, and stearic acids under non-drought stress condition and with oleic, linoleic, and linolenic acids under drought stress condition. Saturated fatty acids (palmitic, stearic, and arachidic) had a negative correlation with linolenic acid under non-stress condition. On the other hand, this fatty acids had a positive correlation with themselves. 
Table 5. Correlation coefficients among yielding and quality attributes of sesame under non drought stress conditions

\begin{tabular}{|c|c|c|c|c|c|c|c|c|c|c|c|c|c|c|c|}
\hline & 1 & 2 & 3 & 4 & 5 & 6 & 7 & 8 & 9 & 10 & 11 & 12 & 13 & 14 & 15 \\
\hline 1 & 1 & & & & & & & & & & & & & & \\
\hline 2 & $0.95 * *$ & 1 & & & & & & & & & & & & & \\
\hline 3 & $-0.39 *$ & $-0.35^{*}$ & 1 & & & & & & & & & & & & \\
\hline 4 & & & $0.62 * *$ & 1 & & & & & & & & & & & \\
\hline 5 & & & $0.33^{*}$ & $0.31 *$ & 1 & & & & & & & & & & \\
\hline 6 & $0.43 * *$ & $0.44 * *$ & $0.66^{* *}$ & $0.34 *$ & $0.58 * *$ & 1 & & & & & & & & & \\
\hline 7 & $0.48 * *$ & $0.51 * *$ & $-0.61 * *$ & $-0.30 *$ & & $-0.54 * *$ & 1 & & & & & & & & \\
\hline 8 & & & & & & & $0.31 *$ & 1 & & & & & & & \\
\hline 9 & & & $0.59 * *$ & $0.97 * *$ & & $0.30 *$ & & & 1 & & & & & & \\
\hline 10 & & & $0.57 * *$ & $0.45^{* *}$ & & $0.42 * *$ & $-0.50 * *$ & & $0.42 * *$ & 1 & & & & & \\
\hline 11 & & & $0.54 * *$ & $0.42 * *$ & & $0.37 *$ & $-0.39 *$ & & $0.41 * *$ & $0.36^{*}$ & 1 & & & & \\
\hline 12 & $0.74 * *$ & $0.80 * *$ & $-0.38^{*}$ & & & $-0.52 * *$ & $0.59 * *$ & & & & & 1 & & & \\
\hline 13 & $-0.68 * *$ & $-0.74 * *$ & $0.58 * *$ & & & $0.54 * *$ & $-0.72 * *$ & & & & & $-0.80 * *$ & 1 & & \\
\hline 14 & $-0.70 * *$ & $-0.76 * *$ & $0.62 * *$ & & & $0.53^{* *}$ & $-0.66^{* *}$ & & & & $0.34 *$ & $-0.73 * *$ & $0.83^{* *}$ & 1 & \\
\hline 15 & & $-0.30 *$ & & & & & & & & $-0.34 *$ & & $-0.37 *$ & $0.42 * *$ & $0.35 *$ & 1 \\
\hline
\end{tabular}

*and **, significantly at the $5 \%$ and $1 \%$ level of probability, respectively, and coefficients not provided was non-significant

1: number of capsule; 2: number of seed; 3: 1000-seed weight; 4: grain yield; 5: biological yield; 6: LAI; 7: number of leaf; 8: oil percent; 9: oil yield; 10: oleic acid;

11: linoleic acid; 12: linolenic acid; 13: palmitic acid; 14: stearic acid; 15: arachidic acid 
Table 6. Correlation coefficients among yielding and quality attributes of sesame under drought stress conditions

\begin{tabular}{|c|c|c|c|c|c|c|c|c|c|c|c|c|c|c|c|}
\hline & 1 & 2 & 3 & 4 & 5 & 6 & 7 & 8 & 9 & 10 & 11 & 12 & 13 & 14 & 15 \\
\hline 1 & 1 & & & & & & & & & & & & & & \\
\hline 2 & $0.92 * *$ & 1 & & & & & & & & & & & & & \\
\hline 3 & & & 1 & & & & & & & & & & & & \\
\hline 4 & $0.33^{*}$ & $0.42 * *$ & $0.53^{* *}$ & 1 & & & & & & & & & & & \\
\hline 5 & & & $0.45^{* *}$ & $0.31 *$ & 1 & & & & & & & & & & \\
\hline 6 & $0.31 *$ & & $0.65^{* *}$ & & $0.48 * *$ & 1 & & & & & & & & & \\
\hline 7 & $0.60 * *$ & $0.61 * *$ & $-0.36^{*}$ & & & $-0.53 * *$ & 1 & & & & & & & & \\
\hline 8 & $0.43^{* *}$ & $0.48 * *$ & & $0.30 *$ & $0.36^{*}$ & & & 1 & & & & & & & \\
\hline 9 & $0.45^{* *}$ & $0.55^{* *}$ & $0.50 * *$ & $0.95^{* *}$ & $0.36^{*}$ & & & $0.55^{* *}$ & 1 & & & & & & \\
\hline 10 & & & $0.46^{* *}$ & & & $0.51 * *$ & $-0.50 * *$ & & & 1 & & & & & \\
\hline 11 & & & $0.39 *$ & & & $0.55^{* *}$ & $-0.53 * *$ & & & $0.56^{* *}$ & 1 & & & & \\
\hline 12 & $0.35^{*}$ & & $-0.40 * *$ & & $-0.36^{*}$ & $-0.63 * *$ & $0.62 * *$ & & & & $-0.33^{*}$ & 1 & & & \\
\hline 13 & & & & $-0.33 *$ & & & & $-0.41 * *$ & $-0.39 *$ & & & & 1 & & \\
\hline 14 & & & $-0.32 *$ & & & $-0.37 *$ & & & & $-0.35^{*}$ & $-0.42 * *$ & & $0.40 * *$ & 1 & \\
\hline 15 & $0.47 * *$ & $0.46^{* *}$ & $-0.50 * *$ & & & $-072 * *$ & $0.74 * *$ & & & $-0.68 * *$ & $-0.74 * *$ & $0.61 * *$ & & $0.31 *$ & 1 \\
\hline
\end{tabular}

*and **, significantly at the $5 \%$ and $1 \%$ level of probability, respectively, and coefficients not provided was non-significant

1: number of capsule; 2: number of seed; 3: 1000-seed weight; 4: grain yield; 5: biological yield; 6: LAI; 7: number of leaf; 8: oil percent; 9: oil yield; 10: oleic acid;

11: linoleic acid; 12: linolenic acid; 13: palmitic acid; 14: stearic acid; 15: arachidic acid 


\section{Discussion}

Plants are frequently subjected to drought stress in their lifecycle. Drought stress leads to photosynthesis inhibition, cell-membrane damage, senescence, and cell death (Turkan, 2011). Under drought stress, reactive oxygen species (ROS) are produced due to an imbalance between light interception and its use. Additionally, ROS, causing damage to a plant cell, also act as a signal and activate some defense mechanisms against stress in living organisms (Hemmati et al., 2018). Generally, drought stress affects all aspects of the growth of plants and also most of its physiological aspects (Hung, 2002). Gupta et al. (1995) reported that drought stress causes a decrease in the rate of plans' growth. The number of leaves and branches also decrease and plants flowering stage begins earlier. Loss of chlorophyll content of leaves is reported under drought circumstances, maintaining the concentrations of chlorophyll stable in this situation helps stabilizing photosynthesis. Regulation of leaf surface is taking place by reducing leaf size and leaf number per plant under drought (Mirzaei et al., 2014). Jane et al. (2010) showed that the drought stress at flowering stage had a significant effect on plant height, capsule size, seed number, seed weight, 1000-seed weight, and other growth characteristics of sesame. The most sensitive stage in the sesame plant was flowering stage (Jain et al., 2010). Lanna et al. (2016) and Mathobo et al. (2017) found that the drought stress led to a severe reduction $(\geq 45 \%)$ in photosynthesis. The stress can inhibit leaf photosynthesis due to alterations in the photosynthetic apparatus, a reduced stomatal aperture, decreased transpiration, changes in light absorption, and alterations of the biochemical pathways associated with $\mathrm{CO}_{2}$ fixation (Farooq, 2009). All of the above points will eventually lead to reduced yield and yield components (Sanchez-Reinoso et al., 2018). In the current study, results indicated that the severe drought stress (irrigation up to $50 \%$ flowering) caused a reduction on growing and yielding attributes such as number of capsule, number of seed, 1000-seed weight, grain yield, biological yield, LAI, and number of leaf. However, moderate stress level had a less negative effect, and in some traits (like number of capsule in the second year, number of seed in the second year, grain yield in the second year, biological yield in both years, and etc.) was higher in compared to the non-stress condition.

Sesame is known as a drought tolerant plant. According to the reports of researcher, there is no significant difference in grain yield and biological yield under mild drought stress level. But, under severe stress occurs a decrease in grain yield and biological yield (Pusadkar et al., 2015). These results are fully consistent with the findings of this study. Also, other researchers reported that confirm the results of severe drought stress reduces yield and yield components of sesame (Ozkan and Kulak, 2013). It seems that the reason for reducing the yield and yield components of sesame under severe stress conditions (irrigation cut at 50\% flowering) can be due to decreased food absorption due to osmotic loss of soil and reduction of the available water content of the plant (Ozkan and Kulak, 2013).

The results showed that the effect of seed weight on grain yield is greater than the other two components, ie, the number of seeds and seeds of the capsule. In the second year of the experiment, the number of seed and number of capsule were higher than the first year, but the grain yield was the opposite. Yield is the result of the efficiency of the plant in using solar radiation during the growing season. In this regard, the plant needs sufficient leaf surface which should be distributed evenly and should cover the earth surface completely (Mirzaei et al., 2014). Decreases in LAI and number of leaf under severe stress have been reported in many plant species including Artemisia aпnиа L. 
(Aftab et al., 2011), S. indicum (Bazrafshan and Ehsanzadeh, 2014), Foeniculum vulgare Mill. (Askari and Ehsanzadeh, 2015), and Triticum dicoccum L. (Tabatabaei and Ehsanzadeh, 2016) which confirms the results of this study. As plant response to drought stress varies across genotypes and is strongly affected by environment and genotype by environment interaction, the use of physiological traits as an indirect selection would be important in augmenting yield-based selection procedures (Lonbani and Arzani, 2011). Genotypes that differ in drought adaptive mechanisms serve as an important resource to study the variation in drought adaption in crop plants (Basu et al., 2016). In the current research was observed LAI affected by interaction effects of drought $\times$ genotype.

The results of this study showed that the foliar application of iron nano-chelate and fulvic acid, alone or in combination together, in most of the yielding traits led to an increase in the mean of this trait in compared to the control (non-foliar application). Reported that the improvement of 1000-seed weight due to the application of iron in comparison with the control (non-application) was due to the optimal combination of micronutrient and main nutrient elements in the reproductive stages. This favorable optimization eventually improves the accumulation of photosynthetic materials in the seeds, resulting in heavier seeds production (Baybordi and Mamedov, 2010). Iron deficiency reduces chlorophyll content and thus the yield and dry matter of the plant was reduced, so the solubility of iron nano-chelates increases biological yield in compared to the control treatment (Boghori et al., 2014). Foliar application of iron nano-chelate due to its high surface area and high solubility (increased absorption capacity), and on the other hand, the foliar application of fulvic acid, due to the presence of high organic matter, caused increases the photosynthetic capacity of the plant and allocates them to the reproductive parts has increased the yield components of the plant (Tousi et al., 2014).

Humic and fulvic acid enhance the permeability of the cell membrane and thus facilitate the entry of potassium into the cell, which increases cellular pressure and cell division. On the other hand, increasing energy in the cells leads to the production of chlorophyll and increases the plant's photosynthesis (Tadayyon et al., 2017). After this important factor in the growth process of the plant, nitrogen uptake in the cell is exacerbated and the nitrate production decreases and eventually the plant production and its yield increase (Moraditochaee, 2012).

It was reported that external application of folic acid increased seed weight and yield of bean (Stakhova et al., 2000). There is little research about the foliar application of folic acid. However, in this regards, can be mentioned the application of folic acid and its beneficial effects on the growth, yield, and quality of some herbs such as flaxseed oil (Emam et al., 2011), beans (Zewail et al., 2011) and wheat (Vician and Kovacik, 2013). A significant effect of fulvic acid solution on growth and yield of potato plant was reported (Ibrahim et al., 2015). The results of this study are consistent with the findings of the other researchers.

The amount of oil and protein content of sesame seeds varies depending on the cultivar and environmental conditions. Accordingly, it was reported that significantly different on number of capsules, grain yield, and oil content of sesame cultivars (Mehrabizadeh and Ehanzadeh, 2012). In the study, the lowest oil content and the highest protein percent was reported under drought stress in seed filling stage of soybean (Divsalar et al., 2016).

Sesame oil, consisting of approximately $50 \%$ seed weight, is mainly composed of fatty acids, oleic (18:1), linoleic (18:2), linolenic (18:3), palmitic (16:0) and stearic (18:0) acids (Kim et al., 2006). The major components in sesame oil are unsaturated fatty acids (mainly oleic and linoleic acids), which contribute significantly to human nutrition (Were 
et al., 2006). In the present study, the identified acids are mentioned above, which six fatty acids (saturated fatty acids: palmitic, stearic, arachidic, and unsaturated fatty acids: oleic, linoleic, linolenic) had for over $85 \%$ of the total. Lack of water during vegetative or reproductive growth stage would be the limiting factor for growth, while it could be a way to enhance levels of secondary metabolites (Kim et al., 2006). The significant differences in drought treatment were observed in oil content and fatty acids composition, which is in line with the results of Kim et al. (2006).

It was reported that the amount of sesame fatty acids is strongly affected by the genotype and the response of the different cultivars is various under environmental conditions (Kadkhodaei et al., 2014). The results of the study showed that unsaturated fatty acids under stress condition and saturated fatty acids under non-stress condition had the higher means. Reductions of fatty acids can be due to the inhibition of the synthesis of unsaturated and saturated fatty acids and their abnormal activity, which results in a decrease in oil content and a change in the composition of the fatty acids (Baldini et al., 2000). The behavior of plants in response to environmental and developmental conditions can change, which, instead of affecting the yielding traits (seed number and number of capsules and 1000-seed weight, etc.), can affect the synthesis of secondary metabolites and bioactive compounds (Ozkan and Kulak, 2013). In a research, drought stress increased the amount of oleic fatty acid in two sesame cultivars, which is consistent with the results of this study (Ozkan and Kulak, 2013).

It has been reported that the amount of saturated and unsaturated fatty acids of sesame oil was affected by environmental conditions and fertilizer treatments and had a different reactivity to these treatments (Rezvani Moghadam et al., 2014). By increasing drought stress, the amount of oleic acid decreased in two sesame cultivars, but the amount of linoleic acid was not affected by drought stress (Ozkan and Kulak, 2013). In a research on the different genotype of sesame under drought stress, the effect of these two factors (drought and genotype) on the amount of oil and the composition of essential oil fatty acids was reported (Kadkhodaei et al., 2014).

\section{Conclusions}

The results showed that the drought stress, especially severe stress (irrigation up to $50 \%$ flowering), reduced number of capsule, number of seed, 1000-seed weight, grain yield and biological yield, as well as seed oil content. On the other hand, the solubility of iron nano-chelate alone or in combination with fulvic acid improves the yielding traits (number of capsule, number of seed, 1000-seed weight, grain yield and biological yield) and oil content of the seed. Between the genotype examined, Halil genotype showed a significant superiority in compared to Dashtestan genotype in terms of most traits. The amounts of saturated fatty acids (palmitic and stearic) under non-stress condition and the unsaturated fatty acids (oleic and linoleic) under drought stress condition were increased. Dashtestan genotype showed the highest amount of saturated fatty acid and Halil genotype with the highest amount of unsaturated fatty acids. Finally, the results showed that severe drought stress (irrigation up to $50 \%$ flowering, equivalent to $65 \mathrm{BBCH}$ ) led to a decrease in the quantitative and qualitative yield that it can be increased by foliar application of iron nano-chelate and organic compounds such as fulvic acid. 


\section{REFERENCES}

[1] Aftab T., Khan, M. M. A., Da Silva, J. A. T. (2011): Role of salicylic acid in promoting salt stress tolerance and enhanced artemisinin production in Artemisia annua L. Journal of Plant Growth Regul 30: 425-435.

[2] Askari, E., Ehsanzadeh, P. (2015): Osmoregulation-mediated differential responses of field-grown fennel genotypes to drought. - Industerial Crops Production 76: 494-508.

[3] Attibayeba, N., Elie, N. M., Serina, N. J. (2010): Description of different growth stages of Sesamum indicum L. using the extended BBCH scale. - Pakestan Journal of Nutrition 9(3): 235-239.

[4] Bagheri, E., Masood Sinaki, J., Baradaran Firoozabadi, M., Abedini Esfhlani, M. (2013): Evaluation of salicylic acid foliar application and drought stress on the physiological traits of sesame (Sesamum indicum L.) cultivars. - Iranian Journal of Plant Physiology 3(4): 809-816.

[5] Baldini, M., Givanardi, R., Vanozzi, G. P. (2000): Effect of different water availability on fatty acid composition of the oil in standard and high oleic sunflower hybrids. - In: Proceedings of XV international sunflower conference Toulouse, pp: 79-84.

[6] Basu, S., Ramegowda, V., Kumar, A., Pereira, A. (2016): Plant adaptation to drought stress. - F1000Res. 5: F1000 Faculty Rev-1554. doi: 10.12688/f1000research.7678.1.

[7] Bazrafshan, A. H., Ehsanzadeh, P. (2014): Growth, photosynthesis and ion balance of sesame (Sesamum indicum L.) genotypes in response to $\mathrm{NaCl}$ concentration in hydroponic solutions. - Photosynthetica 52: 134-147.

[8] Baybordi, A., Mamedov, G. (2010): Evaluation of application methods efficiency of zinc and iron for canola (Brassica napus L.). - Notulae Scientia Biologicale 2(1): 94103.

[9] Boghori, M., Shamsi, H., Morovati, A. (2014): Effect of nano-iron chelate on yield and amount iron and rate oil of sesame cultivate Darab-14. - Journal of Plant Ecophysiology 18(6): 69-79.

[10] Dahmardeh, M., Poodineh, Z., Fakheri, B. A. (2015): Effects of humic and folic acids on quantity and quality related traits of button mushroom (Agaricus bisporus). Biological Forum-An International Journal 7(1): 823-828.

[11] Divsalar, M., Tahmasbi Sarvestani, Z., Modares Sanavi, S. A. M., Hamidi, A. (2016): The evaluation of drought stress impact as irrigation withholding at reproductive stages on the quantitative and qualitative performance of soybean cultivars. - Agricultural Crop Management 18(2): 481-493.

[12] Emam, M. M., El-Sweify, A. H., Helal, N. M. (2011): Efficiencies of some vitamins in improving yield and quality of flax plant. - African Journal of Agricultural Research 6(18): 4362-4369.

[13] Farhoosh, R., Hadad Khodaparast, M. H., Sharif, A. (2009): Bene hull oil as stable and antioxidative vegetable oil. - European Journal of Lipid Science and Technology 111: 1259-1265.

[14] Farooq, M., Wahid, A., Kobayashi, N., Fujita, D., Basra, S. M. A. (2009): Plant drought stress: Effects, mechanisms, and management. - Agronomy for Sustainable Development 29: 185-212.

[15] Gharby, S., Harhar, H., Bouzobaa, Z., Asdadi, A., El-Yadini, A., Charrouf, Z. (2017): Chemical characterization and oxidative stability of seeds and oil of sesame grown in Morocco. - Journal of Saudi Society of Agricultural Sciences 16: 105-111.

[16] Gupta, S. N., Dahiya, B. S., Malik, B. P. S., Bishnoi, N. R. (1995): Response of chickpea to water deficits and drought stress. - Haryana Agriculture University Research Journal 25: 11-19.

[17] Hemmati, K., Ebadi, A., Khomari, S., Sedghi, M. (2018): Influence of ascorbic acid and 24-epibrassinolide on physiological characteristics of pot marigold under water-stress condition. - Journal of Plant Interactions 13(1): 362-372. 
[18] Hung, B. (2002): Role of root morphological and physiology characteristics in droughtresistant of plant. - Plant Environmental Interaction 39-64.

[19] Hussein, Y., Amin, G., Gahin, H. (2016): Antioxidant activities during drought stress resistance of sesame (Sesamum indicum L.) plant by salicylic acid and kinetin. Research Journal of Botany 11(1-3): 1-8.

[20] Ibrahim, M. F. M., AbdEl-Gawad, H. G., Bondok, A. M. (2015): Physiological impacts of potassium citrate and folic acid on growth, yield and some viral diseases of potato plants. - Middle East Journal of Agriculture 4(3): 477-598.

[21] Jain, S., Yue-Lioang, R., Mei-wang, L. E., Ting-Xian, Y., Xiao-Wen, Y., Hong-Ving, Z. (2010): Effect of drought stress on sesame growth and yield characteristics and comprehensive evaluation of drought tolerance. - Chinese Journal of Oil Crops Sciences 4: 42-48.

[22] Kadkhodaei, A., Razmjoo, J., Zahedi, M., Pessarakli, M. (2014): Oil content and composition of sesame (Sesamum indicum L.) genotypes as affected by irrigation regimes. - Journal of the American Oil Chemists' Society 91: 1737-1744.

[23] Kassab, O., Noemani, E., El-Zeiny, A. H. (2005): Influence of some irrigation system and water regimes on growth and yield of sesame plants. - Journal of Agronomy 4: 220-224.

[24] Kim, K. S., Ryu, S. K., Chung, H. G. (2006): Influence of drought stress on chemical composition of sesame seed. - Korean Journal of Crop Science 51(1): 73-80.

[25] Ladan Moghadam, A., Vattani, H., Baghaei, N., Keshavarz, N. (2012): Effect of different levels of fertilizer nano Iron chelates on growth and yield characteristics of two varieties of Spinach (Spinacia oleracea L.): Varamin 88 and Viroflay. - Research of Applied Sciences, Engineering, and Technology 4(12): 4813-4818.

[26] Lanna, A. C., Mitsuzono, S. T., Terra, T. G. R., Vianello, R. P., Carvalho, M. A. F. (2016): Physiological characterization of common bean (Phaseolus vulgaris L.) genotypes, water-stress induced with contrasting response towards drought. Australian Journal of Crop Science10: 1-6.

[27] Lonbani, M., Arzani, A. (2011): Morpho-physiological traits associated with terminal drought stress tolerance in triticale and wheat. - Agronomy Research 9: 315-329.

[28] Malacrida, C. R., Kimura, M., Jorge, N. (2011): Characterization of a high oleic oil extracted from papaya (Carica papaya L.) seeds. - Ciênc. Tecnol. Aliment., Campinas, 31(4): 929-934.

[29] Maleki-Farahani, S., Aghighi Shahverdi, M. (2015): Evaluation of the effect of nonoiron fertilizer in compare to iron chelate fertilizer on qualitative and quantitative yield of saffron. - Agricultural Crop Management 17(1): 155-168.

[30] Masoud Sinaki, M. J., Majidi Heravan, E., Shirani Rad, A. H., Noormohammadi, G., Zarei, G. H. (2007):The effects of water deficit during growth stages of canola (Brassica napus L.). - Am-Eurasian J Agric Environ Sci 2: 417-422.

[31] Mathobo, R., Maraisa, D., Steyn, J. M. (2017): The effect of drought stress on yield, leaf gaseous exchange and chlorophyll fluorescence of dry beans (Phaseolus vulgaris L.). - Agricultural Water Management 180: 118-125.

[32] Mehrabizadeh, Z., Ehsanzadeh, P. (2012): A study on physiological attributes and grain yield of sesame cultivars under different soil moisture regimes. - Agricultural Crop Management 13(2): 75-88.

[33] Miao, Z. H., Li, K., Liu, P. Y., Li, Z., Yang, H., Zhao, Q., Chang, M., Yang, Q., Zhen, L., Xu, C. Y. (2018): Natural humic-acid based phototheranostic agent. - Advanced Healthcare Materials 7(7): 1701202. DOI: 10.1002/adhm.201701202.

[34] Mirzaei, A., Naseri, R., Vafa, P., Moradi, M. (2014): Effects of drought stress on qualitative and quantitative traits of mungbean. - International Journal of Agricultural and Biosystems Engineering 8(2): 148-152. 
[35] Moraditochaee, M. (2012): Effects of humic acid foliar spraying and nitrogen fertilizer management on the yield of peanut (Arachis hypogaea L.) in Iran. - ARPN Journal of Agricultural and Biological Science 7(4): 289-293.

[36] Ozkan, A., Kulak, M. (2013): Effects of water stress on growth, oil yield, fatty acid composition and mineral content of Sesamum indicum L. - Journal of Animal and Plant Sciences. 23(6): 1686-1690.

[37] Pusadkar, P. P., Kokiladevi, E., Bonde, S. V., Mohite, N. R. (2015): Sesame (Sesamum indicum L.) importance and its high-quality seed oil: A Review. - Trends in Biosciences 8(15):3900-06.

[38] Prajapat, K. (2010): Intercropping of sesame (Sesamum imdicum L.) with Mungbean under varing lebels of sulphur. Thesis of Master of Scinece. - Swami Keshwanand Rajasthan Agricultural University, Bikaner.

[39] Rezvani-Moghadam, P., Amiri, M. B., Seyedi, S. M. (2014): Effect of organic and biofertilizers application on yield, oil content and fatty acids composition of sesame (Sesamum indicum L.). - Iranian Journal of Crop Science 16 (3): 209-221.

[40] Sanchez-Reinoso, A. D., Ligarreto-Moreno, G. A., Restrepo-Diaz, H. (2018): Physiological and biochemical responses of common bush bean to drought. - Notulae Botanicae Horti Agrobotanici Cluj-Napoca 46(2): 393-401.

[41] Stakhova, L. N., Stakhov, L. F., Ladygin, V. G. (2000): Effects of exogenous folic acid on the yield and amino acid content of the seed of Pisum sativum L. and Hordeum vulgare L. - Applied Biochemistry and Microbiology 36(1): 98-103.

[42] Tabatabaei, S., Ehsanzadeh, P. (2016): Photosynthetic pigments, ionic and antioxidative behavior of hulled tetraploid wheat in response to NaCl. - Photosynthetica 54: 340-350.

[43] Tadayyon, A., Beheshti, S., Pessarakli, M. (2017): Effects of sprayed humic acid, iron, and zinc on quantitative and qualitative characteristics of niger plant. - Journal of Plant Nutrition 40: 1644-1650.

[44] Thornton, P. K., Ericksen, P. J., Herrero, M., Challinor, A. J. (2014): Climate variability and vulnerability to climate change: a review. - Global Change Biol. 20: 3313-3328.

[45] Tousi, P., Tajbakhsh, M., Esfahani, M. (2014): Effect of spray application of nano-Fe chelate, amino acid compounds and magnetic water on protein content and fatty acids composition of oil of soybean (Glycine max L.) in different harvest time. - Iranian Journal of Crop Sciecnce 16(2): 125-136.

[46] Turkan, I. (2011): Plant responses to drought and salinity stress. - Academic Press.

[47] Vician, M., Kovacik, P. (2013): The effect of folic application of mg-titanit fertilizer on phytomass, chlorophyll production and the harvest of winter wheat. - Mendel Net 3: $162-168$.

[48] Were, B. A., Onkware, A. O., Gudu, S., Welander, M., Carlsson, A. S. (2006): Seed oil content and fatty acid composition in East African sesame (Sesamum indicum L.) accessions evaluated over 3 years. - Field Crop Research 97: 254-260.

[49] Zewail, R. M., Khder, Z. M., Mady, M. A. (2011): Effect of potassium, some antioxidants, phosphoric acid and napthalen acetic acid (NAA) on growth and productivity of faba bean plants (Faba vulgaris L.). - Annals of Agricultural Science Moshtohor Journal 49(1): 53-64. 